\title{
Aerobic and Anaerobic Metabolism of Trimethylamine, Dimethylamine and Methylamine in Hyphomicrobium $\mathbf{x}$
}

\author{
|By J. B. M. MEIBERG AND W. HARDER \\ Department of Microbiology, Biological Centre, University of Groningen, Kerklaan 30, \\ Haren (Gr.), The Netherlands
}

(Received 22 December 1977)

\begin{abstract}
Hyphomicrobium strain $\mathrm{x}$ was grown on trimethylamine and dimethylamine as the sole sources of carbon and energy under both aerobic and anaerobic conditions and the enzymes involved in the metabolism of these compounds were investigated. During aerobic growth of the organism on trimethylamine, accumulation and subsequent utilization of dimethylamine was observed. When the organism was grown on trimethylamine under anaerobic conditions in the presence of nitrate, a sequential accumulation and utilization of dimethylamine and methylamine was found. In cell-free extracts of Hyphomicrobium $\mathrm{x}$ grown on trimethylamine or dimethylamine under both aerobic and anaerobic conditions the following enzyme activities were detected: trimethylamine dehydrogenase, dimethylamine dehydrogenase, $\gamma$-glutamylmethylamide synthetase, $N$-methylglutamate dehydrogenase, methanol dehydrogenase, formaldehyde dehydrogenase, formate dehydrogenase and hydroxypyruvate reductase. Under neither growth condition were any of the following enzyme activities detected: trimethylamine mono-oxygenase, dimethylamine monooxygenase, trimethylamine- $N$-oxide aldolase (demethylase) and primary-amine dehydrogenase. Trimethylamine dehydrogenase and dimethylamine dehydrogenase were partially purified from bacteria grown on dimethylamine and the results suggest that in Hyphomicrobium $\mathrm{x}$ a novel enzyme, namely dimethylamine dehydrogenase, participates in the oxidation of dimethylamine.
\end{abstract}

\section{INTRODUCTION}

Various micro-organisms can grow aerobically on trimethylamine, dimethylamine and methylamine as the sole source of carbon and energy, and the metabolism of these compounds has been studied extensively (Colby \& Zatman, 1973; Anthony, 1975; Boulton \& Large, 1977). The initial catabolism of trimethylamine in methylotrophic bacteria may proceed by one of two different pathways. The first route involves the direct demethylation to dimethylamine and formaldehyde, catalysed by trimethylamine dehydrogenase (Colby \& Zatman, 1971), while in the other pathway the initial attack is an oxygenation of trimethylamine to trimethylamine $N$-oxide mediated by trimethylamine mono-oxygenase (Large, Boulton \& Crabbe, 1972). The $N$-oxide is subsequently demethylated by trimethylamine $N$-oxide aldolase (demethylase) to dimethylamine and formaldehyde (Myers \& Zatman, 1971; Large, 1971).

The oxidation of dimethylamine to methylamine and formaldehyde in Pseudomonas aminovorans involves a secondary-amine mono-oxygenase (Eady \& Large, 1969; Eady, Jarman \& Large, 1971) and this enzyme was also reported to function in Bacterium 4 6 6 and some other organisms (Colby \& Zatman, 1973). Until recently (Meiberg \& Harder, 1976) no other enzyme involved in the oxidation of dimethylamine had been reported, except that 
the purified trimethylamine dehydrogenase from Bacterium 4B6 (Colby \& Zatman, 1974) and a partially purified trimethylamine dehydrogenase from Hyphomicrobium vulgare NQ-521 (Large \& McDougall, 1975) displayed some activity towards dimethylamine. Large \& McDougall (1975) also reported a dimethylamine dehydrogenase activity in an enzyme preparation obtained from $H$. vulgare NQ-521, but they attributed this activity to a contaminating organism. The product of the oxidation of dimethylamine, namely methylamine, may be oxidized directly (Eady \& Large, 1968, 1971) or via $N$-methylglutamate (Hersh, Peterson \& Thompson, 1971; Loginova, Shishkina \& Trotsenko, 1976; Bamforth \& Large, 1977).

We recently found that hyphomicrobia can be enriched and isolated by an anaerobic technique (Attwood \& Harder, 1972) using trimethylamine or dimethylamine as the substrate and nitrate as terminal electron acceptor (J. B. M. Meiberg, unpublished results). In fact, pure cultures of several Hyphomicrobium isolates, previously obtained from enrichments with methanol or methylamine (Attwood \& Harder, 1972), could grow on trimethylamine and dimethylamine, both aerobically and anaerobically with nitrate. Under the latter conditions it appeared to be highly improbable that dimethylamine mono-oxygenase was involved in the catabolism of trimethylamine and dimethylamine and we therefore decided to investigate the metabolism of these compounds in one of the isolates available. Since the physiology and biochemistry of Hyphomicrobium $\mathrm{x}$ is well documented (Harder \& Attwood, 1978), this organism was chosen for the present study which describes some aspects of its growth on trimethylamine and dimethylamine under both aerobic and anaerobic conditions and implicates a novel enzyme, namely dimethylamine dehydrogenase, in the oxidation of dimethylamine.

A preliminary report of part of this work has been published (Meiberg \& Harder, 1976).

\section{METHODS}

Maintenance and growth of the organism. Hyphomicrobium strain x (Attwood \& Harder, 1972) was grown in mineral salts medium containing (per litre of deionized water): $\left(\mathrm{NH}_{4}\right)_{2} \mathrm{SO}_{4}, 1.0 \mathrm{~g} ; \mathrm{MgSO}_{4} .7 \mathrm{H}_{2} \mathrm{O}, 0.2 \mathrm{~g}$; $\mathrm{NaH}_{2} \mathrm{PO}_{4} . \mathrm{H}_{2} \mathrm{O}, 0.5 \mathrm{~g} ; \mathrm{K}_{2} \mathrm{HPO}_{4}, 1.55 \mathrm{~g}$; and trace element solution (Vishniac \& Santer, 1957), 0.2 ml. The $\mathrm{pH}$ of the medium was 7.2. After it had been heat-sterilized and cooled, filter-sterilized solutions of the various methylated amines were added to a final concentration of $10 \mathrm{mM}$ (aerobic experiments) or $20 \mathrm{~mm}$ (anaerobic experiments).

The organism was maintained on the above mineral salts medium supplemented with $0.34 \%$ (w/v) methylammonium chloride and $1.5 \%(\mathrm{w} / \mathrm{v})$ Bacto-agar, and was transferred bimonthly; slopes were incubated at $30^{\circ} \mathrm{C}$ for $7 \mathrm{~d}$ and then stored at $4{ }^{\circ} \mathrm{C}$.

Bacteria were grown in a 41 fermenter described by Harder, Visser \& Kuenen (1974), filled with 31 of medium. During growth, the $\mathrm{pH}$ was maintained at 7.0 by periodic addition of sterile alkali and the culture was stirred and aerated at $301 \mathrm{~h}^{-1}$. The temperature was maintained at $30^{\circ} \mathrm{C}$. During anaerobic growth, $\mathrm{KNO}_{3}$ was added in portions as indicated in the individual experiments. In these experiments air was replaced by nitrogen gas from which traces of oxygen had been removed by passing it through a solution of dihydroriboflavin (Strauss \& Nickerson, 1961). For both aerobic and anaerobic experiments, a $200 \mathrm{ml}$ culture of the organism, grown on the same substrate in $500 \mathrm{ml}$ conical flasks on a shaker at $30^{\circ} \mathrm{C}$, was used as an inoculum.

Growth was monitored by measuring the absorbance of the culture at $433 \mathrm{~nm}$; one absorbance unit corresponded to $0.22 \mathrm{mg}$ dry wt $\mathrm{ml}^{-1}$.

For enzyme assays in crude cell-free extracts, bacteria from different growth phases, as indicated in the individual experiments, were harvested by centrifugation at $15000 \mathrm{~g}$ for $10 \mathrm{~min}$ at $4{ }^{\circ} \mathrm{C}$, washed once with $50 \mathrm{~mm}$-potassium phosphate buffer pH 7.0 and used immediately or stored at $-20^{\circ} \mathrm{C}$. Trimethylamine and dimethylamine dehydrogenases were purified from bacteria harvested at the end of the active growth phase.

Bacterium $5 \mathrm{H} 2$ was obtained from Dr L. J. Zatman, University of Reading. It was grown in the above mineral salts medium in conical flasks on a shaker at $30^{\circ} \mathrm{C}$ with $0.3 \%(\mathrm{w} / \mathrm{v})$ trimethylamine as the carbon and energy source. Bacteria were harvested at the end of the exponential growth phase.

Preparation of cell-free extracts. Bacteria $(0.5 \mathrm{~g}$ wet $\mathrm{wt})$ were suspended in $4 \mathrm{ml}$ of $50 \mathrm{~mm}$-potassium phosphate buffer pH 7.0 and $0.5 \mathrm{~g}$ of acid-washed glass beads (diam. $0.11 \mathrm{~mm}$ ) was added to the suspension. 
The bacteria were disrupted at $20 \mathrm{kHz}$ in a $100 \mathrm{~W}$ ultrasonic disintegrator for $2.5 \mathrm{~min}$ at $0{ }^{\circ} \mathrm{C}$. Whole cells, debris and glass beads were removed by centrifuging at $25000 \mathrm{~g}$ for $20 \mathrm{~min}$. The resulting supernatant was used as the crude cell-free extract.

Dry weight determination. Duplicate samples of $200 \mathrm{ml}$ were removed from the culture, centrifuged, washed once with deionized water and dried to constant weight at $110^{\circ} \mathrm{C}$.

Chemical estimations. Protein was measured by the method of Lowry et al. (1951), using bovine serum albumin as a standard.

Methylated amines were measured as follows: $10 \mathrm{ml}$ samples were withdrawn from the cultures at appropriate intervals, and bacteria were removed by membrane filtration (pore size $0.2 \mu \mathrm{m}$ ). The concentration of the methylated amines in the filtrates was determined by gas chromatography using a Pye Unicam series 104 chromatograph with a heated dual flame ionization detector. A glass column $(1.9 \mathrm{~m} \times 2 \mathrm{~mm}$ i.d.) was used, packed with Carbopack B, coated with GP $4 \%$ Carbowax $20 \mathrm{M}$ plus $0.8 \% \mathrm{KOH}$. The column oven temperature was $120^{\circ} \mathrm{C}$, and the detector oven, $150{ }^{\circ} \mathrm{C}$. Nitrogen was used as the carrier gas at a flow rate of $10 \mathrm{ml}$ $\mathrm{min}^{-1}$. Before injection, $1.6 \%(\mathrm{w} / \mathrm{v}) \mathrm{KOH}$ was added to the samples to a final concentration of $0.8 \%(\mathrm{w} / \mathrm{v})$. Standards were prepared from mono-, di- and trimethylammonium chlorides dried with $\mathrm{Mg}\left(\mathrm{ClO}_{4}\right)_{2}$.

Nitrite was measured by a modification of the method of Egami \& Taniguchi (1963) as follows: to $4 \mathrm{ml}$ of appropriately diluted culture filtrate were added $0.5 \mathrm{ml}$ of $1 \%(\mathrm{w} / \mathrm{v})$ sulphanilamide in $1.2 \mathrm{M}-\mathrm{HCl}$ and $0.5 \mathrm{ml}$ of $0.02 \%$ (w/v) $N$-1-naphthylethylenediamine dihydrochloride. After $10 \mathrm{~min} A_{540}$ was measured and the nitrite concentration was read from a calibration curve made with known solutions of $\mathrm{NaNO}_{2}$ in water.

Nitrate was measured using the spectrophotometric method of Goldsmith et al. (1973). Nitrite absorbs light at $210 \mathrm{~nm}$ whereas methylated amines do not. The procedure for estimating nitrate in the presence of nitrite was to determine nitrite, as described above, and then subtract the contribution of the nitrite to the total $A_{210}$ of the sample (as observed with standard nitrite solutions) from the measured $A_{210}$ of the sample containing both nitrate and nitrite. A standard solution of $1.25 \mathrm{~mm}-\mathrm{KNO}_{3}$ was used for calibration purposes.

Formaldehyde was prepared by heating aqueous solutions of paraformaldehyde in a sealed glass vial at $110^{\circ} \mathrm{C}$ overnight, and was determined by the method of Nash (1953).

Enzyme assays. All spectrophotometric assays were performed using a Hitachi Perkin-Elmer 124 doublebeam recording spectrophotometer equipped with a constant temperature cuvette housing (Charles Goffin, De Bilt, The Netherlands). The incubation temperature was $30^{\circ} \mathrm{C}$ in all assays.

Trimethylamine dehydrogenase and dimethylamine dehydrogenase were assayed by the method of Colby \& Zatman (1973), except that $\mathrm{KCN}$ was omitted and assays were done anaerobically. The reaction mixture contained (in $1 \mathrm{ml}$ ): $100 \mu \mathrm{mol}$ sodium pyrophosphate buffer $\mathrm{pH}$ 7.7; $0.08 \mu \mathrm{mol}$ 2,6-dichlorophenolindophenol (DCPIP); $2 \mu \mathrm{mol}$ phenazine methosulphate (PMS); extract; and $3 \mu \mathrm{mol}$ trimethylamine or dimethylamine. The reaction was started by adding the substrate, and the initial rate of decrease in $A_{600}$ was taken as a measure of enzyme activity.

DCPIP-dependent formaldehyde dehydrogenase was assayed by the method of Johnson \& Quayle (1964), except that $0.08 \mu \mathrm{mol}$ DCPIP was used.

NAD/glutathione-linked formaldehyde dehydrogenase was assayed by the method of Johnson \& Quayle (1964), modified by using $0.4 \mu \mathrm{mol} \mathrm{NAD}{ }^{+}$and $3 \mu \mathrm{mol}$ glutathione (GSH).

Methanol dehydrogenase and formaldehyde dehydrogenase were measured by a modification of the polarographic method of Harder \& Attwood (1975). The reaction mixture contained (in $3 \mathrm{ml}$ ): $300 \mu \mathrm{mol}$ Tris/HCl buffer $\mathrm{pH} 9 \cdot 0 ; 4 \mu \mathrm{mol}$ PMS; $45 \mu \mathrm{mol} \mathrm{NH} \mathrm{NH}_{4} \mathrm{Cl}$; extract; and $16 \mu \mathrm{mol}$ methanol or $30 \mu \mathrm{mol}$ formaldehyde. The reaction was started by adding substrate.

Hydroxypyruvate reductase was assayed by the method of Blackmore \& Quayle (1970), except that 50 mM-potassium phosphate $\mathrm{pH} 7.0$ was used as a buffer.

$\gamma$-Glutamylmethylamide synthetase was measured by a modification of the method of Loginova et al. (1976). The complete reaction mixture contained (in $1 \mathrm{ml}$ ): $16 \mu \mathrm{mol} \mathrm{Tris} / \mathrm{HCl}$ buffer $\mathrm{pH} 7.6 ; 5 \mu \mathrm{mol}\left[{ }^{14} \mathrm{C}\right]$ methylamine $(1.0 \mu \mathrm{Ci}) ; 10 \mu \mathrm{mol} \mathrm{2-mercaptoethanol;} 5 \mu \mathrm{mol} \mathrm{ATP} ; 5 \mu \mathrm{mol} \mathrm{MnCl}_{2} ; 10 \mu \mathrm{mol} \mathrm{L}$-glutamate; and extract. The reaction was started by adding $\left[{ }^{14} \mathrm{C}\right]$ methylamine and was allowed to continue for various periods of time (up to $30 \mathrm{~min}$ ). Controls without ATP or $\mathrm{Mn}^{2+}$ or with boiled extract were included. The reaction was stopped by the addition of $0 \cdot 1 \mathrm{ml}$ of $30 \%(\mathrm{w} / \mathrm{v})$ trichloroacetic acid. Denatured protein was removed by centrifugation and $25 \mu \mathrm{l}$ of the supernatant was applied to a cellulose thin-layer chromatogram and developed in two dimensions with 2-methylpropan-2-ol/ethyl methyl ketone/water/aq. $\mathrm{NH}_{4} \mathrm{OH}$ (sp.gr. 0.91) (40:30:20:10, by vol.) followed by phenol/formic acid/water (500:13:167, by vol.). The plates were dried overnight and scanned to locate the radioactive spot of $\gamma$-glutamylmethylamide, using a Berthold LB 2723 scanner (Charles Goffin, De Bilt, The Netherlands). The radioactive areas were scraped from the plate and counted by liquid scintillation using a mixture of Triton/toluene $(1: 2, \mathrm{v} / \mathrm{v})$ containing $1 \%(\mathrm{w} / \mathrm{v}) 2,5-$ diphenyloxazole.

The following enzyme activities were assayed by unmodified published methods: trimethylamine mono- 
oxygenase, dimethylamine mono-oxygenase and trimethylamine- $N$-oxide demethylase (Colby \& Zatman, 1973); primary-amine dehydrogenase (Eady \& Large, 1968); NAD-dependent formate dehydrogenase (Johnson \& Quayle, 1964); $N$-methylglutamate dehydrogenase (Bamforth \& Large, 1977).

Purification of trimethylamine and dimethylamine dehydrogenases. Bacteria were grown anaerobically with dimethylamine as the substrate, and were harvested by centrifugation as described above. A bacterial suspension ( $1 \mathrm{~g}$ wet wt per $4 \mathrm{ml}$ of $50 \mathrm{~mm}$-potassium phosphate buffer $\mathrm{pH} \mathrm{7.0)}$ was disrupted ultrasonically for $7.5 \mathrm{~min}$ at $0^{\circ} \mathrm{C}$ as described above. To the crude cell-free extract $\left(7.5 \mathrm{mg}^{\circ}\right.$ protein $\left.\mathrm{ml}^{-1}\right)$, solid ammonium sulphate was added to give $50 \%$ saturation, while maintaining the $\mathrm{pH}$ at 7.5 with $10 \%(\mathrm{v} / \mathrm{v}) \mathrm{NH}_{4} \mathrm{OH}$. After $1 \mathrm{~h}$ at $0{ }^{\circ} \mathrm{C}$ the precipitate was removed by centrifuging at $13000 \mathrm{~g}$ for $20 \mathrm{~min}$. More solid ammonium sulphate was added to bring the clear supernatant to $70 \%$ saturation. After $1 \mathrm{~h}$ at $0{ }^{\circ} \mathrm{C}$ the precipitate was collected by centrifugation and dissolved in $4 \mathrm{ml}$ of $20 \mathrm{~mm}$-sodium phosphate buffer $\mathrm{pH} 7 \cdot 5$. This fraction, which contained most of the enzyme activity, was dialysed for $16 \mathrm{~h}$ against 31 of $20 \mathrm{~mm}$-sodium phosphate buffer $\mathrm{pH} 7.5$, with one change of buffer. The dialysed fraction was then applied to a column $(1.5 \times 27 \mathrm{~cm})$ of DEAEcellulose (Whatman, DE32), previously equilibrated with 20 mM-sodium phosphate buffer $\mathrm{pH} 7.5$. Protein was eluted with a linear gradient of 0 to $0.5 \mathrm{M}-\mathrm{NaCl}$ in 20 mM-sodium phosphate buffer $\mathrm{pH} 7.5$; fractions of $3.3 \mathrm{ml}$ were collected. Trimethylamine dehydrogenase activity was eluted between 0.16 and $0.23 \mathrm{M}-\mathrm{NaCl}$ and dimethylamine dehydrogenase activity between 0.20 and $0.29 \mathrm{M}-\mathrm{NaCl}$. The fractions containing trimethylamine dehydrogenase (nos 38 to 49) and those containing dimethylamine dehydrogenase (nos 50 to 70) (see Fig. 5) were pooled separately and each concentrated to $2.3 \mathrm{ml}$ by ultrafiltration using an Amicon PM10 membrane. The purification procedure is summarized in Table 2.

Chemicals. Methylammonium chloride, dimethylammonium chloride and trimethylammonium chloride were obtained from Merck. Bovine serum albumin was from Poviet Producten, Amsterdam, The Netherlands. Carbopack B was from Supelco, Bellefonte, Pennsylvania, U.S.A. Other chemicals and reagents were from Sigma or Fluka, Buchs, Switzerland. Biochemicals were from Boehringer. $\left[{ }^{14} \mathrm{C}\right]$ Methylamine was from The Radiochemical Centre, Amersham. $\gamma$-Glutamylmethylamide was synthesized as described by Lichtenstein (1942).

\section{RESULTS}

\section{Aerobic growth of Hyphomicrobium $\mathrm{x}$ on trimethylamine and dimethylamine}

With trimethylamine as the sole carbon and energy source, Hyphomicrobium $\mathrm{x}$ grew at a specific growth rate of $0 \cdot 10 \mathrm{~h}^{-1}$ (Fig. 1), which is similar to that observed in media containing methanol (Harder, Attwood \& Quayle, 1973).

During aerobic growth on trimethylamine, accumulation and subsequent utilization of dimethylamine were observed (Fig. 1). The kinetics of the utilization of trimethylamine and of accumulation of dimethylamine indicated that an almost stoicheiometric conversion of trimethylamine into dimethylamine occurred during part of the exponential growth phase (from 17 to $24 \mathrm{~h}$ ). During this period the organism apparently was unable to metabolize dimethylamine to any appreciable extent and growth was exclusively due to the degradation of trimethylamine to dimethylamine. After the trimethylamine concentration had dropped to below $1.5 \mathrm{~mm}$, the apparent inhibition of dimethylamine catabolism was relieved and the concentration of dimethylamine in the medium decreased. At the end of exponential growth, when trimethylamine was undetectable, growth was exclusively at the expense of dimethylamine. These results suggest that dimethylamine is an intermediate in the metabolism of trimethylamine by Hyphomicrobium $\mathrm{x}$.

When the organism was grown on $10 \mathrm{~mm}$-dimethylamine as the initial substrate, accumulation and subsequent utilization of methylamine were observed (Fig. 2). The kinetics of the accumulation and disappearance of these compounds were such that concomitant utilization of both dimethylamine and methylamine by the organism must be postulated over the whole period of exponential growth. Initially ( 5 to $8 \mathrm{~h}$ after the start of the experiment), when the concentration of dimethylamine in the culture was above $4 \mathrm{~mm}$, the rate of methylamine production from dimethylamine was higher than the rate of its utilization, whereas at later stages of growth methylamine was utilized faster than it was formed. These results indicate that methylamine may be an intermediate in the metabolism of dimethylamine by Hyphomicrobium x. Methylamine was not excreted during growth on trimethylamine (Fig. 1), possibly due to the low concentration $(5 \mathrm{mM})$ of the accumulated dimethylamine. 


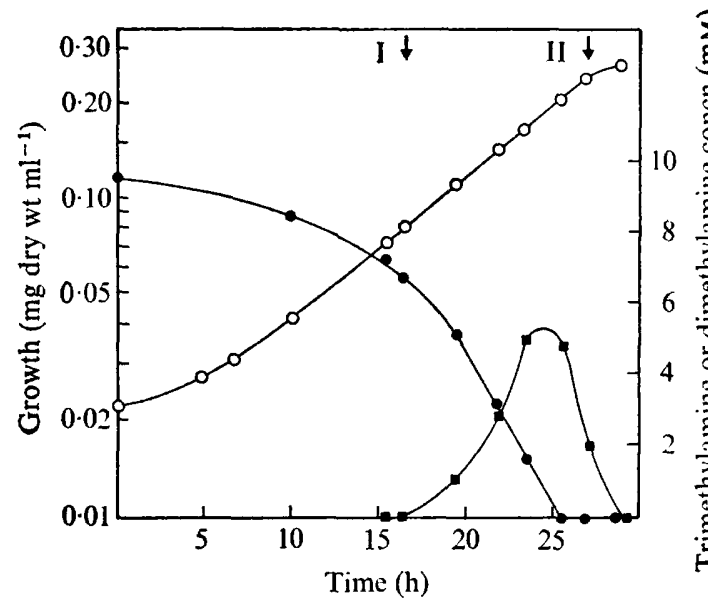

Fig. 1

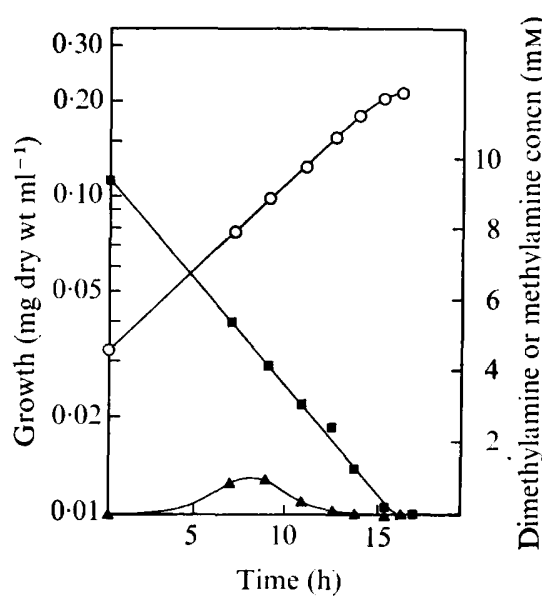

Fig. 2

Fig. 1. Aerobic growth of Hyphomicrobium $\mathrm{x}$ on trimethylamine: $\bigcirc$, growth; and, $\mathbf{\square}$, dimethylamine concentrations in the culture. Enzyme activities were measured in cell-free extracts prepared from culture samples taken at two different stages of growth, as indicated by the arrows I and II.

Fig. 2. Aerobic growth of Hyphomicrobium $\mathrm{x}$ on dimethylamine: $\bigcirc$, growth; $\mathbf{a}$, dimethylamine and, $\boldsymbol{\Delta}$, methylamine concentrations in the culture.

\section{Anaerobic growth of Hyphomicrobium $\mathrm{x}$ on trimethylamine and dimethylamine in the presence of nitrate}

Growth of Hyphomicrobium $\mathrm{x}$ under denitrifying conditions on trimethylamine and dimethylamine was much slower than that observed in the presence of oxygen. Initially the experiments were carried out in media in which $50 \mathrm{~mm}$-nitrate was used as the electron acceptor. However, nitrite rapidly accumulated under these conditions resulting in a complete inhibition of growth [although Sperl \& Hoare (1971) reported that the major end-product of nitrate respiration in hyphomicrobia is nitrogen]. Therefore, in subsequent experiments, nitrate was added to the culture in three separate portions and although nitrite accumulation still occurred, the concentration did not become high enough to inhibit growth completely; however, some growth inhibition was still apparent (Figs 3,4).

Anaerobic growth of Hyphomicrobium $\mathrm{x}$ on trimethylamine revealed a complicated pattern of substrate utilization (Fig. 3). As was observed during aerobic growth (Fig. 1), the initial growth was almost exclusively due to the oxidation of trimethylamine to dimethylamine. Very little, if any, of the dimethylamine produced was metabolized until the concentration of trimethylamine in the culture was very low. During the subsequent oxidation of dimethylamine, accumulation of methylamine was observed. However, as had been observed during aerobic growth on dimethylamine, the data indicated a concomitant utilization of dimethylamine and methylamine, although the rate of production of methylamine was initially higher than its rate of utilization. In these experiments exponential growth (specific growth rate $0.025 \mathrm{~h}^{-1}$ ) of the organism was only observed in the early stages of the batch culture when the nitrite concentration was low. Growth of Hyphomicrobium $\mathrm{x}$ stopped completely when the electron acceptor was exhausted from the culture, although the concentration of the carbon source was still sufficient to support growth.

In contrast to the results obtained for aerobic growth of Hyphomicrobium $\mathrm{x}$ on dimethylamine, anaerobic growth on this substrate did not lead to any accumulation of methylamine (Fig. 4). Growth of the organism was only exponential in the early stages of the batch culture, 


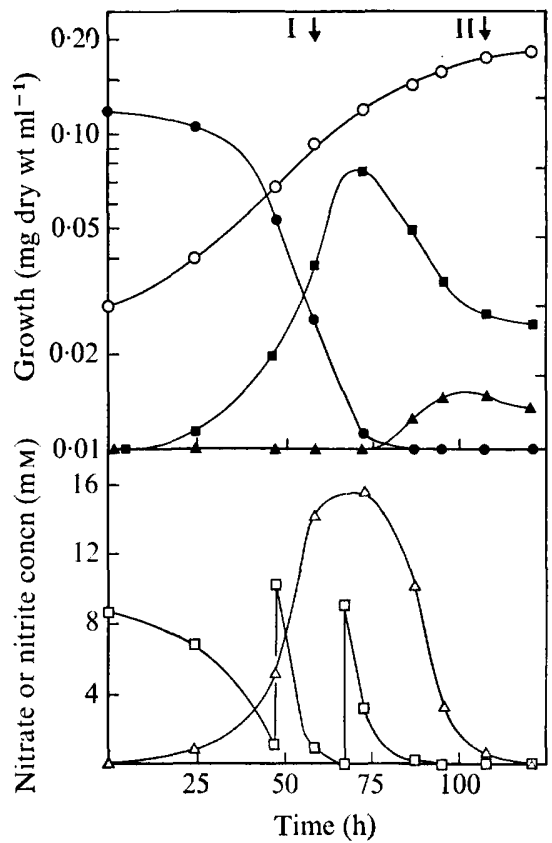

Fig. 3

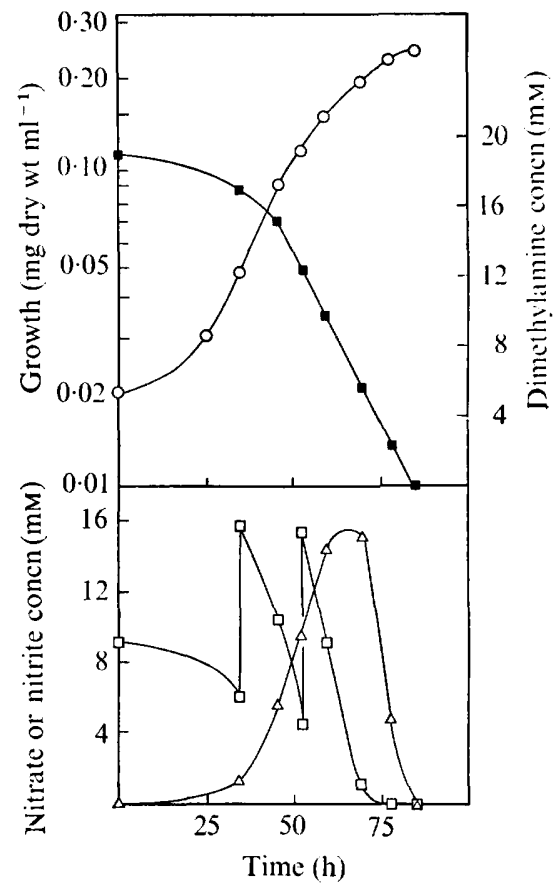

Fig. 4

Fig. 3. Anaerobic growth of Hyphomicrobium $\mathrm{x}$ on trimethylamine in the presence of nitrate: $\mathrm{O}$, growth; $\boldsymbol{\theta}$, trimethylamine, $\mathbf{v}$, dimethylamine, $\boldsymbol{\Delta}$, methylamine, $\square$, nitrate and, $\Delta$, nitrite concentrations in the medium. Enzyme activites were measured in cell-free extracts prepared from culture samples taken at different stages of growth, as indicated by the arrows I and II. Nitrate was supplied to the culture in three separate portions.

Fig. 4. Anaerobic growth of Hyphomicrobium $\mathrm{x}$ on dimethylamine in the presence of nitrate: $O$, growth; $\square$, dimethylamine, $\square$, nitrate and, $\triangle$, nitrite concentrations in the medium. Nitrate was supplied to the culture in three separate portions.

when the nitrite concentration was very low. The specific growth rate of $0.05 \mathrm{~h}^{-1}$ observed initially gradually declined as the nitrite concentration increased to approximately $15 \mathrm{~mm}$ and continued to decline until the dimethylamine was exhausted.

\section{Activities of enzymes involved in methylated amine metabolism in Hyphomicrobium $\mathrm{x}$}

Cell-free extracts of Hyphomicrobium $\mathbf{x}$, grown under aerobic or anaerobic conditions on trimethylamine, dimethylamine or methylamine, were analysed for enzymes previously implicated in the microbial metabolism of methylated amines (see Anthony, 1975). The results (Table 1) indicated that, in Hyphomicrobium $\mathrm{x}$, trimethylamine dehydrogenase (EC 1.5.99.7) was the only enzyme present for the oxidation of trimethylamine. This enzyme was also found in bacteria grown on dimethylamine, but was absent from extracts prepared from methylamine-grown bacteria, indicating that it was induced by both trimethylamine and dimethylamine. Neither trimethylamine mono-oxygenase nor trimethylamine- $N$-oxide aldolase (demethylase) (EC 4.1.2.-) was detected, although both enzymes were present in cell-free extracts of trimethylamine-grown Bacterium $5 \mathrm{H} 2$ (Table 1), indicating that the failure to demonstrate these enzymes in extracts of Hyphomicrobium $\mathrm{x}$ was not due to inadequacies of the assay system used. The oxidation of dimethylamine in Hyphomicrobium $\mathrm{x}$ is also mediated by a dehydrogenase and in this respect the organism is different from a number of other methylotrophs in which dimethylamine mono-oxygenase has been implicated in the metabolism of trimethylamine. As was found for the tri- 
Table 1. Specific activities of various enzymes in crude extracts of Hyphomicrobium $\mathrm{x}$ grown on trimethylamine, dimethylamine or methylamine and of Bacterium $5 \mathrm{H} 2$ grown on trimethylamine

Samples of trimethylamine-grown Hyphomicrobium $\mathrm{x}$ were taken at two stages of growth, as indicated by the arrows (I and II) in Figs 1 and 3; organisms grown on dimethylamine and methylamine were taken at the end of the active growth phase. Specific activities are expressed as nmol substrate transformed $\min ^{-1}$ (mg protein) ${ }^{-1}$.

Abbreviations: TMA, trimethylamine-grown; DMA, dimethylamine-grown; MA, methylamine-grown; aer, anaer, cultivation under aerobic and anaerobic conditions, respectively; ND, not determined.

\section{Enzyme}

Trimethylamine dehydrogenase (PMS)

Trimethylamine mono-oxygenase (NADPH)

Trimethylamine- $N$-oxide aldolase (demethylase)

Dimethylamine dehydrogenase (PMS)

Dimethylamine mono-oxygenase

(NADPH)

Primary-amine dehydrogenase (PMS)

$\gamma$-Glutamylmethylamide synthetase

$N$-Methylglutamate dehydrogenase

(DCPIP)

Methanol dehydrogenase (PMS)

Formaldehyde dehydrogenase (PMS)

Formaldehyde dehydrogenase

(DCPIP)

Formaldehyde dehydrogenase (NAD/GSH)

Formate dehydrogenase (NAD)

Hydroxypyruvate reductase (NADH)

\begin{tabular}{|c|c|c|c|c|c|c|c|c|}
\hline & & $H y_{l}$ & phomic & robium & & & & $\begin{array}{l}\text { cterium } \\
5 \mathrm{H} 2\end{array}$ \\
\hline TM & & DMA & MA & TMA & anaer & DMA & MA & TMA \\
\hline I & II & & & I & II & & & \\
\hline 21 & 18 & 7 & 0 & 37 & 36 & 22 & 0 & 0 \\
\hline 0 & 0 & 0 & 0 & 0 & 0 & 0 & 0 & 22 \\
\hline 0 & 0 & 0 & ND & 0 & 0 & 0 & ND & 168 \\
\hline 6 & 10 & 8 & 0 & 24 & 36 & 43 & 0 & 0 \\
\hline 0 & 0 & 0 & 0 & 0 & 0 & 0 & 0 & 7 \\
\hline ND & 0 & 0 & 0 & ND & 0 & 0 & 0 & 0 \\
\hline ND & 2 & 11 & 1 & ND & 1 & 2 & 5 & ND \\
\hline ND & 4 & 5 & 6 & ND & 8 & 6 & 8 & ND \\
\hline ND & 342 & 554 & 357 & ND & 140 & 92 & 236 & 0 \\
\hline ND & 348 & 641 & 192 & ND & 106 & 56 & 205 & 0 \\
\hline ND & 26 & 29 & 32 & ND & 25 & 31 & 113 & 6 \\
\hline ND & 0 & 0 & 0 & ND & 0 & 0 & 0 & 175 \\
\hline ND & 129 & 183 & 177 & ND & 191 & 180 & 763 & 21 \\
\hline ND & 1429 & 2459 & 2984 & ND & 2280 & 2096 & 2380 & ND \\
\hline
\end{tabular}

methylamine dehydrogenase, the dimethylamine dehydrogenase displayed its highest activity in cells grown anaerobically on dimethylamine, whereas the enzyme was absent from cell-free extracts of methylamine-grown cells. Activity of dimethylamine monooxygenase (EC 1.14.99.-) was not detected in extracts of Hyphomicrobium $\mathrm{x}$, although it was detected in trimethylamine-grown Bacterium $5 \mathrm{H} 2$.

The metabolism of methylamine, a product of the action of dimethylamine dehydrogenase, is likely to proceed via $\gamma$-glutamylmethylamide and $N$-methylglutamate to formaldehyde. Activities of $\gamma$-glutamylmethylamide synthetase (EC 6.3.4.12) and $N$-methylglutamate dehydrogenase (EC 1.5.99.5) were detected in extracts of Hyphomicrobium x grown on all methylated amines tested, whereas the primary-amine dehydrogenase was not present (Table 1). The formaldehyde generated in the successive oxidations may be utilized for either of two purposes. It can be oxidized to formate and $\mathrm{CO}_{2}$ for the generation of energy by the action of primary-alcohol dehydrogenase (Harder \& Attwood, 1975) or dye-linked formaldehyde dehydrogenase (Johnson \& Quayle, 1964) and formate dehydrogenase, respectively. Alternatively it may be utilized for the assimilation of one-carbon units via the icl- $^{-}$serine pathway (Harder et al., 1973; Attwood \& Harder, 1977); the high levels of hydroxypyruvate reductase activity (Table 1) are consistent with the operation of this latter pathway during growth on methylated amines.

In order to investigate whether the observed accumulation of dimethylamine in the 


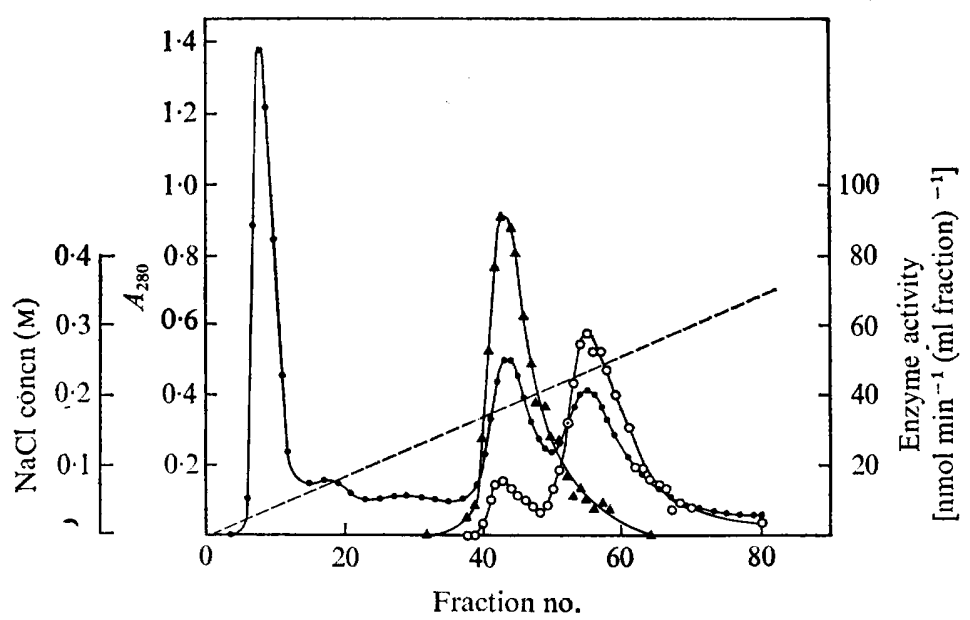

Fig. 5. DEAE-cellulose chromatography of trimethylamine dehydrogenase and dimethylamine dehydrogenase from Hyphomicrobium $\mathrm{x}$, grown under anaerobic conditions with dimethylamine as the growth substrate. The 50 to $70 \%$ ammonium sulphate fraction (containing $59 \mathrm{mg}$ protein) was chromatographed using a DEAE-cellulose column, previously equilibrated with 20 mM-sodium phosphate buffer $\mathrm{pH} \mathrm{7.5}$. Protein was eluted with a gradient of 0 to $0.5 \mathrm{M}-\mathrm{NaCl}$ (not completely shown) in the same buffer and $3.3 \mathrm{ml}$ fractions were collected; the flow rate was $24 \mathrm{ml} \mathrm{h}^{-1} . \bullet, A_{280}$; $\Delta$, trimethylamine dehydrogenase activity; $O$, dimethylamine dehydrogenase activity;---, $\mathrm{NaCl}$ gradient.

\section{Table 2. Partial purification of trimethylamine and dimethylamine dehydrogenases from Hyphomicrobium $\mathrm{x}$}

Total activities are expressed as nmol substrate transformed $\mathrm{min}^{-1}$ and specific activities as nmol substrate transformed $\mathrm{min}^{-1}$ (mg protein) ${ }^{-1}$.

Abbreviations: TMA, trimethylamine dehydrogenase activity; DMA, dimethylamine dehydrogenase activity.

\begin{tabular}{|c|c|c|c|c|c|c|c|c|c|c|}
\hline \multirow[b]{2}{*}{ Fraction } & \multirow{2}{*}{$\begin{array}{l}\text { Vol. } \\
\text { (ml) }\end{array}$} & \multirow{2}{*}{$\begin{array}{l}\text { Total } \\
\text { protein } \\
\text { (mg) }\end{array}$} & \multicolumn{2}{|c|}{$\begin{array}{r}\begin{array}{c}\text { Total } \\
\text { activity }\end{array} \\
\end{array}$} & \multicolumn{2}{|c|}{$\begin{array}{l}\text { Specific } \\
\text { activity }\end{array}$} & \multicolumn{2}{|c|}{$\begin{array}{c}\begin{array}{c}\text { Recovery } \\
(\%)\end{array} \\
\end{array}$} & \multicolumn{2}{|c|}{$\begin{array}{c}\begin{array}{c}\text { Purification } \\
\text { factor }\end{array} \\
\text { ? }\end{array}$} \\
\hline & & & TMA & DMA & TMA & DMA & TMA & DMA & TMA & DMA \\
\hline ree extract & 40 & 300 & 5105 & 6313 & $17 \cdot 0$ & $21 \cdot 0$ & 100 & 100 & 1.0 & $1 \cdot 0$ \\
\hline $\begin{array}{l}\text { m sulphate fraction } \\
\% \text { saturation }\end{array}$ & 5 & $73 \cdot 5$ & 4030 & 3887 & $54 \cdot 8$ & 52.9 & 78.9 & $61 \cdot 6$ & $3 \cdot 2$ & $2 \cdot 5$ \\
\hline $\begin{array}{l}\text { ictions nos } 38 \text { to } 49 \\
\text { ellulose eluate* }\end{array}$ & $2 \cdot 3$ & $3 \cdot 6$ & 653 & 88 & $180 \cdot 4$ & $24 \cdot 3$ & $12 \cdot 8$ & $1 \cdot 4$ & $10 \cdot 6$ & $1 \cdot 2$ \\
\hline $\begin{array}{l}\text { tions nos } 50 \text { to } 70 \\
\text { lulose eluate* }\end{array}$ & $2 \cdot 3$ & $7 \cdot 2$ & 349 & 1919 & $48 \cdot 6$ & $267 \cdot 6$ & $6 \cdot 8$ & $30 \cdot 4$ & $2 \cdot 9$ & $12 \cdot 7$ \\
\hline
\end{tabular}

* Assayed after concentration by ultrafiltration.

dissimilation of trimethylamine during growth of Hyphomicrobium $\mathrm{x}$ on this compound (Figs 1,3) was due to repression of the synthesis of dimethylamine dehydrogenase, cell-free extracts were prepared at different stages of growth (arrows I and II in Figs 1 and 3). The results (Table 1) indicated that the failure of the cells to metabolize dimethylamine sufficiently during part of the exponential phase of growth on trimethylamine cannot be attributed to the absence of dimethylamine dehydrogenase, although the activity of the enzyme is somewhat lower during the initial stages of growth. 


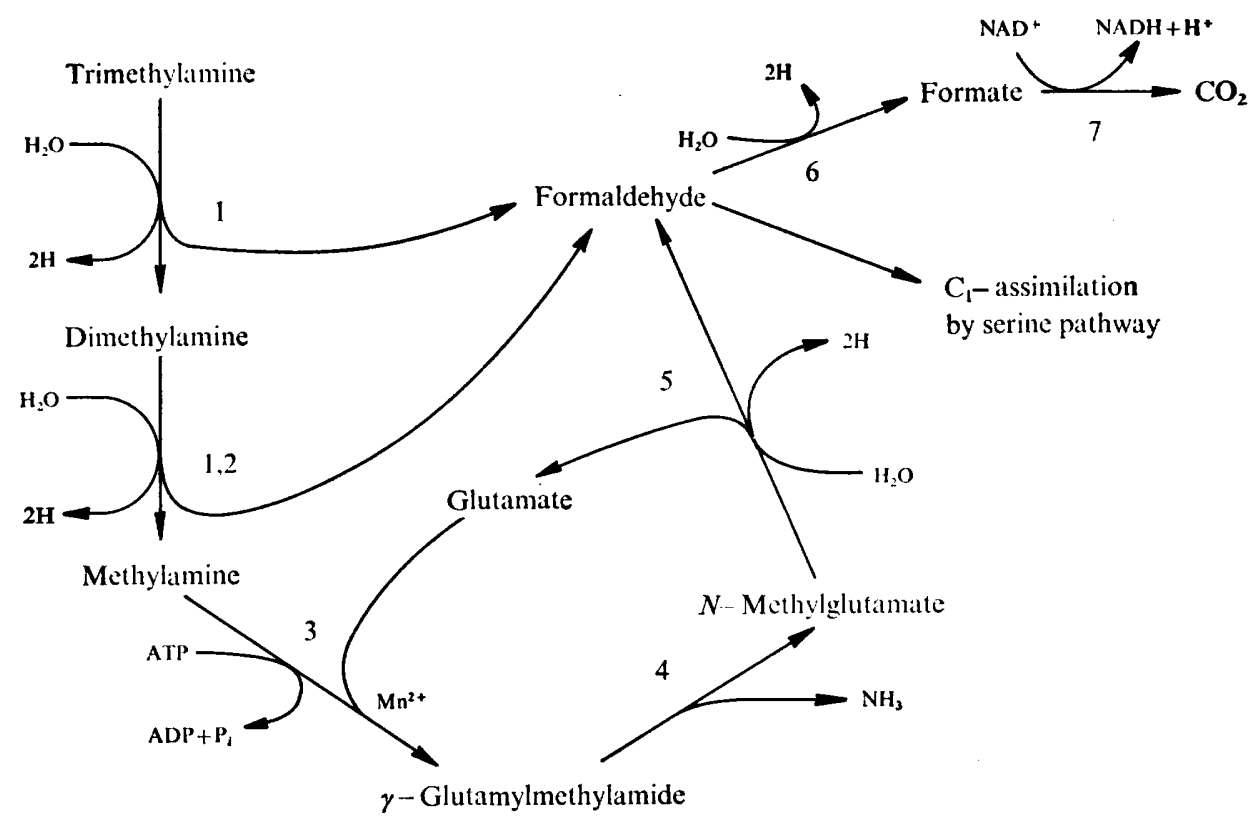

Fig. 6. Proposed scheme for trimethylamine, dimethylamine and methylamine metabolism in Hyphomicrobium x. The enzymes of the pathway are: (1), trimethylamine dehydrogenase (EC 1.5.99.7); (2), dimethylamine dehydrogenase; (3), $\gamma$-glutamylmethylamide synthetase (EC 6.3.4.12); (4), enzyme not yet characterized (see Loginova et al., 1976); (5), $N$-methylglutamate dehydrogenase (EC 1.5.99.5); (6), formaldehyde dehydrogenase; (7), formate dehydrogenase (EC 1.2.1.2).

\section{Partial purification of trimethylamine and dimethylamine dehydrogenase activities from Hyphomicrobium $\mathrm{X}$}

The data of Table 1 suggest that the oxidation of dimethylamine in Hyphomicrobium $\mathbf{x}$ is mediated by a novel enzyme. However, an alternative explanation could be that the observed oxidation of dimethylamine by the dye-linked dehydrogenase was due to a dual substrate specificity of the trimethylamine dehydrogenase, although the ratio of the two activities observed in cell-free extracts of bacteria grown under different conditions suggested otherwise. Furthermore, preliminary experiments on the stability of the two enzyme activities indicated a different behaviour towards heat treatment. For instance, the ratio of trimethylamine dehydrogenase activity to dimethylamine dehydrogenase activity in cell-free extracts changed from 1.7 to 5.3 upon heating the extract for $20 \mathrm{~min}$ at $60^{\circ} \mathrm{C}$. To substantiate further the probability that the two enzyme activities were associated with different proteins, both enzymes were partially purified from cells grown anaerobically on dimethylamine (Table 2, Fig. 5). Although the activities of trimethylamine dehydrogenase and dimethylamine dehydrogenase were not completely separated after DEAE-cellulose column chromatography (Fig. 5), the results indicated that they are indeed associated with different proteins. A small peak of dimethylamine-oxidizing activity which co-chromatographed with the trimethylamine dehydrogenase was probably due to a minor activity of the trimethylamine dehydrogenase towards dimethylamine.

\section{DISCUSSION}

On the basis of the results obtained in the present study, we propose a pathway for the metabolism of methylated amines in Hyphomicrobium $\mathrm{x}$ as shown in Fig. 6. Trimethylamine is oxidized by a dye-linked dehydrogenase which also displays some activity (approximately 
$15 \%$ of the activity with trimethylamine as the substrate) towards dimethylamine. A similar dimethylamine-oxidizing activity was found for the purified trimethylamine dehydrogenase of Bacterium 4B6 (Colby \& Zatman, 1974) and also for a partially purified trimethylamine dehydrogenase of Hyphomicrobium vulgare NQ-521 (Large \& McDougall, 1975). However, such a substrate specificity is not necessarily an intrinsic property of all trimethylamine dehydrogenases since the enzyme purified from Bacterium w3Al did not show any activity with dimethylamine as the substrate (Steenkamp \& Mallinson, 1976). The dimethylamine is further oxidized by another dye-linked dehydrogenase which most probably is specific for dimethylamine and does not show activity towards trimethylamine (Fig. 5). Both enzymes are present during growth on dimethylamine and trimethylamine (Table 1). Similar to the situation reported for $H$. vulgare 3 (Trotsenko, Loginova \& Shishkina, 1974) and $H$. vulgare $\mathrm{ZV}$ (Loginova et al., 1976), in Hyphomicrobium $\mathrm{x}$ methylamine is oxidized via $\gamma$-glutamylmethylamide and $N$-methylglutamate. The formaldehyde generated in the above reactions can either be oxidized to $\mathrm{CO}_{2}$ via formate or assimilated via the icl- serine pathway (Fig. 6; Harder et al., 1973; Harder \& Attwood, 1975; Attwood \& Harder, 1977).

The activities of the enzymes implicated in the metabolism of trimethylamine and dimethylamine in aerobically grown Hyphomicrobium $\mathrm{x}$ were too low to account for the growth rate of the organism. Although the observed growth rates under aerobic conditions were considerably higher than under anaerobic conditions in the presence of nitrate (Figs 1 to 4 ), the activities of trimethylamine and dimethylamine dehydrogenases were lower (Table 1). Despite several attempts to increase the activities of these enzymes in cell-free extracts by changing both the conditions used for the preparation of extracts or in the assay procedure, they remained low in aerobically grown cells. However, a decrease in oxygen tension in the culture caused an increase in the activity of these enzymes and it was therefore not unexpected to find the highest activities under anaerobic conditions.

During growth of Hyphomicrobium $\mathrm{x}$ on trimethylamine, accumulation of intermediates of the degradative pathway of this compound was observed in the medium (Figs 1 and 3). A similar phenomenon has been described during growth of Micrococcus sp. on trimethylamine (Tate \& Alexander, 1976). These workers reported that accumulation of dimethylamine in the medium was affected by the nature of the inorganic nitrogen source and by the initial $\mathrm{pH}$ value. It is not known whether similar changes of the medium may affect the accumulation of dimethylamine from trimethylamine by cultures of Hyphomicrobium X. In the course of our work we observed that trimethylamine was a potent competitive inhibitor of the partially purified dimethylamine dehydrogenase. Since we also observed that trimethylamine dehydrogenase shows some activity towards dimethylamine, we suggest the following explanation for the accumulation of dimethylamine. During the initial stages of the growth of Hyphomicrobium $\mathrm{x}$ on trimethylamine, any activity of dimethylamine dehydrogenase will be effectively inhibited by the relatively high concentration of trimethylamine in the medium. And, although the dimethylamine produced by the action of trimethylamine dehydrogenase may be further oxidized by this enzyme, accumulation of dimethylamine in the medium may result from poor kinetics of the enzyme for this substrate. Only when the trimethylamine concentration is decreased to a low level will the inhibition of dimethylamine dehydrogenase be relieved, resulting in the decrease of the concentration of dimethylamine in the culture. Further studies with purified enzymes are required to substantiate this hypothesis.

We suggest that dimethylamine dehydrogenase plays a major role in the metabolism of trimethylamine and dimethylamine in those Hyphomicrobium spp. that are able to grow on these compounds under both aerobic and denitrifying conditions. However, it is not peculiar to all representatives of the genus, since $H$. vulgare $\mathrm{NQ}$ (Eady et al., 1971) and $H$. vulgare ZV (Loginova et al., 1976) contain dimethylamine mono-oxygenase during (aerobic) growth on trimethylamine. Also, the further metabolism of this compound in $H$. vulgare zV differs from that in Hyphomicrobium $\mathbf{x}$ in that the former organism contains NAD-linked 
$N$-methylglutamate dehydrogenase and formaldehyde dehydrogenase, whereas in the latter organism these enzymes are dye-linked. If $H$. vulgare $\mathrm{NQ}$ and $\mathrm{ZV}$ are able to grow on trimethylamine under denitrifying conditions, it would be of interest to see if dimethylamine dehydrogenase is involved in the metabolism of these compounds.

\section{REFERENCES}

Anthony, C. (1975). The biochemistry of methylotrophic micro-organisms. Science Progress, Oxford 62, 167-206.

Attwood, M. M. \& Harder, W. (1972). A rapid and specific enrichment procedure for Hyphomicrobium spp. Antonie van Leeuwenhoek 38, 369-378.

ATTWOOD, M. M. \& HARdeR, W. (1977). Isocitrate lyase activity in Hyphomicrobium spp.: a critical reappraisal. FEMS Microbiology Letters 1, 25-30.

Bamforth, C. W. \& LARge, P. J. (1977). Solubilization, partial purification and properties of $N$ methylglutamate dehydrogenase from Pseudomonas aminovorans. Biochemical Journal 161, 357-370.

Blackmore, M. A. \& Quayle, J. R. (1970). Microbial growth on oxalate by a route not involving glyoxylate carboligase. Biochemical Journal 118, 53-59.

Boulton, C. A. \& Large, P. J. (1977). Synthesis of certain assimilatory and dissimilatory enzymes during bacterial adaptation to growth on trimethylamine. Journal of General Microbiology 101, 151-156.

Colby, J. \& Zatman, L. J. (1971). The purification and properties of a bacterial trimethylamine dehydrogenase. Biochemical Journal 121, 9P-10p.

Colby, J. \& Zatman, L. J. (1973). Trimethylamine metabolism in obligate and facultative methylotrophs. Biochemical Journal 132, 101-112.

Colby, J. \& Zatman, L. J. (1974). Purification and properties of the trimethylamine dehydrogenase of Bacterium 4B6. Biochemical Journal 143, 555567.

Eady, R. R. \& Large, P. J. (1968). Purification and properties of an amine dehydrogenase from Pseudomonas AMI and its role in growth on methylamine. Biochemical Journal 106, 245-255.

EADY, R. R. \& LARge, P. J. (1969). Bacterial oxidation of dimethylamine, a new mono-oxygenase reaction. Biochemical Journal 111, 37P-38P.

EADY, R. R. \& LARGE, P. J. (1971). Microbia! oxidation of amines. Spectral and kinetic properties of the primary amine dehydrogenase of Pseudomonas AM1. Biochemical Journal 123, 757-771.

EADY, R. R., JARMAN, T. R. \& LARGE, P. J. (1971). Microbial oxidation of amines. Partial purification of a mixed-function secondary-amine oxidase system from Pseudomonas aminovorans that contains an enzymically active cytochrome- $P$ 420-type haemoprotein. Biochemical Journal 125, 449-459.

Egami, F. \& TANiguchi, S. (1963). Nitrate. In Methods of Enzymatic Analysis, 1st edn, pp. 636639. Edited by H. U. Bergmeyer. New York and London: Academic Press.
Goldsmith, J., Livoni, J. P., NorberG, C. L. \& SEgEL, I. H. (1973). Regulation of nitrate uptake in Penicillium chrysogenum by ammonium ion. Plant Physiology 52, 362-367.

HARder, W. \& ATtwood, M. M. (1975). Oxidation of organic $\mathrm{C}_{1}$ compounds by Hyphomicrobium spp. Antonie van Leeuwenhoek 41, 421-429.

HARDER, W. \& ATtwood, M. M. (1978). Biology, physiology and biochemistry of Hyphomicrobia. Advances in Microbial Physiology 17 (in the Press).

Harder, W., Atrwood, M. M. \& Quayle, J. R. (1973). Methanol assimilation by Hyphomicrobium sp. Journal of General Microbiology 78, 155-163.

HARder, W., VisSer, K. \& Kuenen, J. G. (1974). Laboratory fermenter with an improved magnetic drive. Laboratory Practice 23, 644-645.

Hersh, L. B., Peterson, J. A. \& Thompson, A. A. (1971). An $N$-methylglutamate dehydrogenase from Pseudomonas MA. Archives of Biochemistry and Biophysics 145, 115-120.

Johnson, P. A. \& QUAYLE, J. R. (1964). Microbial growth on $C_{1}$ compounds. VI. Oxidation of methanol, formaldehyde and formate by methanolgrown Pseudomonas AM1. Biochemical Journal 93, 281-290.

LARGE, P. J. (1971). Non-oxidative demethylation of trimethylamine $N$-oxide by Pseudomonas aminovorans. FEBS Letters 18, 297-300.

LARge, P. J. \& McDougall, H. (1975). An enzymic method for the microestimation of trimethylamine. Analytical Biochemistry 64, 304-310.

large, P. J., Boulton, C. A. \& Crabbe, M. J. C. (1972). The reduced nicotinamide-adenine dinucleotide phosphate- and oxygen-dependent $N$-oxygenation of trimethylamine by Pseudomonas aminovorans. Biochemical Journal 128, 137P$138 \mathrm{P}$.

LichtensteIn, N. (1942). Preparation of $\gamma$-alkylamides of glutamic acid. Journal of the American Chemical Society 64, 1021-1022.

Loginova, N. V., Shishinina, V. N. \& Trotsenko, YU.A. (1976). Primary metabolic pathways of methylated amines in Hyphomicrobium vulgare. Mikrobiologiya (English translation) 45, 34-40.

Lowry, O. H., Rosebrough, N. J., FARr, A. L. \& RANDALL, R. J. (1951). Protein measurement with the Folin phenol reagent. Journal of Biological Chemistry 193, 265-275.

MeiberG, J. B. M. \& Harder, W. (1976). Aerobic and anaerobic degradation of trimethylamine and dimethylamine by Hyphomicrobium x. Proceedings of the Society for General Microbiology 4, 45.

Myers, P. A. \& ZATMAN, L. J. (1971). The metabolism of trimethylamine $N$-oxide by Bacillus PM6. Biochemical Journal 121, 10P.

NASH, T. (1953). The colorimetric estimation of 
formaldehyde by means of the Hantzsch reaction. Biochemical Journal 55, 416-421.

SPERL, G. T. \& HoARE, D. S. (1971). Denitrification with methanol: a selective enrichment for Hyphomicrobium species. Journal of Bacteriology 108, 733-736.

Steenkamp, D. J. \& Mallinson, J. (1976). Trimethylamine dehydrogenase from a methylotrophic bacterium. I. Isolation and steady-state kinetics. Biochimica et biophysica acta 429, 705719.

Strauss, G. \& Nickerson, W. J. (1961). Photochemical cleavage of water by riboflavin. II. Role of activators. Journal of the American Chemical Society 83, 3187-3191.

TATE, III, R. L. \& ALEXANDER, M. (1976). Microbial formation and degradation of dimethylamine. Applied and Environmental Microbiology 31, 399_ 403.

Trotsenko, Yu. A., Loginova, N. V. \& Shishkina, V. N. (1974). Metabolism of methylamine by Hyphomicrobium. Dokladi Akademii nauk SSSR (Proceedings of the Academy of Sciences of the U.S.S.R.) 216, 1413-1415.

VishniaC, W. \& SANTER, M. (1957). The thiobacilli. Bacteriological Reviews 21, 195-213. 